\title{
Income Levels and Factors That Influence the Unsustainability of Cassava (Manihot Utilissima) Partnership in Lampung Province, Indonesia
}

\author{
Wan Abbas Zakaria; Teguh Endaryanto; Lidya Sari Mas Indah; Lina Marlina ${ }^{1}$; Abdul Mutolib ${ }^{2}$ \\ ${ }^{1}$ Department of Agribusiness, Faculty of Agriculture, University of Lampung, Indonesia \\ ${ }^{2}$ Department of Agricultural Extension, Faculty of Agriculture, University of Lampung, Indonesia \\ http://dx.doi.org/10.18415/ijmmu.v6i4.1096
}

\begin{abstract}
Lampung Province is the largest cassava center in Indonesia. The cassava partnership pattern developed in Lampung as an effort by companies and farmers to increase production and obtain optimal benefits for each party. Unfortunately, many partnerships failed and eventually ended in the middle. This study aims to analyze the income of partner cassava farmers and non-partner cassava farmers and the factors leading to cease of the cassava partnership in Lampung Province, Indonesia.This study was conducted using a survey method in the central locations of cassava production and tapioca agroindustry centers in Lampung Province from July to September 2018. The number of sample farmers was 126 cassava farmers (63 farmers conducted partnerships and 63 farmers had not been in partnership). Data were analyzed by descriptive quantitative method.Analysis of the factors that influence farmers' decisions to do partnership was assessed using logistic regression. Research of cash income of partner cassava farmers was $\mathrm{Rp} 22,855,464.79$ per ha and cash income of non-partner cassava farmers was $\mathrm{Rp}$ 13,819,044.20.The factors that influence the decision of cassava farmers in partnerships were land area, cassava farming experience, and farming income. Although promising, many partnership patterns of agricultural products, particularly cassava in Lampung, have discontinued (break-off partnerships). The unsustainability of cassava partnership in Lampung was caused by the violations committed by farmers by selling their crops to other companies/factories and then the companies/factories paid cheaper price compared to other companies/factories that did not have partnerships with farmers.
\end{abstract}

Keywords: Cassava; Agricultural Partnership; Income; Unsustainability; Lampung

\section{Introduction}

Indonesia is a large producer of cassava in the world (Hermiati, Mangunwidjaja, Sunarti, Suparno, \& Prasetya, 2012; Abidin \& Devi, 2013). Cassava is important because it is considered one of the foodstuffs besides rice, industrial raw materials and animal feed ingredients (Montes, Rodrigues, Cardoso, Camilloto, \& Cruz, 2015; Sugiharto, Yudiarti, Isroli, Widiastuti, \& Putra, 2017). In other words, cassava has a strategic role in supporting food security and industrial drivers from small to 
large scale and from upstream to downstream (Echebiri \& Edaba, 2008; Abidin \& Devi, 2013; Abidin \& Devi, 2013).

Lampung Province in Sumatra is the largest production of cassava in Indonesia (Sugino \& Mayrowani, 2009; Kamal, Hadi, \& Hariyanto, 2014; Fitriani, Unteawati, Mutaqin, \& Sutarni, 2018). Based on data from Department of Agriculture of Food Crops and Horticulture of Lampung Province, there has been a decrease in harvested area and cassava production in Indonesia from 2011 to 2017. In 2011 cassava production was 24.044.025 tons and decreased to 19.046.000 tons. Thus, the harvested area decreased from 1.184.696 Ha to $778.664 \mathrm{Ha}$. This condition illustrates that cassava agribusiness in Indonesia is facing a serious problem and if left unchecked it will threaten the continuity of cassava agribusiness which mostly involves small farmers (BPS Lampung, 2018).

As food, until now there is still a surplus of cassava production compared to the demand for consumption. The cassava balance in Indonesia in 2015 reached a surplus of 1,03 million tons, and it is estimated that the surplus of cassava continues to occur until 2020. In 2016, Indonesia experienced a surplus of cassava amounting to 327,27 thousand tons, in 2017 a surplus of 656,17 thousand tons, in 2018 a surplus of 923,85 thousand tons, while in 2019 and 2020 is estimated to have a surplus of 469,29 thousand tons and 708,31 thousand tons, respectively (MoA, 2016). If it is seen from a macro perspective, there will be a decline in the surplus of cassava in the 2015 to 2020 range from 1.03 million tons to 708,31 thousand tons.

Declining the surplus of cassava amid advances in cultivation technology is a sign that there is a problem in cassava cultivation. Lampung Province is the largest cassava center in Indonesia where nearly one third of cassava production in Indonesia (22 million tons) is produced by Lampung Province (BPS Lampung, 2018). One of the factors supporting the high production of cassava in Lampung is the partnership of cassava between farmers and the companies. The partnership has increased the production and income of partner farmers as well as fulfill cassava demand for the company. Unfortunately, many cassava partnerships in Lampung do not last long. Generally, partnerships last less than five years. The unsustainability of the partnership has an impact on the declining surplus of cassava in Lampung and national level.

Research on cassava has been carried out in Indonesia (Asnawi, 2003; Anggraini, Hasyim, \& Situmorang, 2013; Siburiaan, Sebayang, \& Sihombing, 2013; Thamrin, Merdhiyah, \& Marpaung, 2013). However, those studies have not discussed cassava from the aspect of unsustainability partnerships, and the factors leading to unsustainability partnerships. In other words, previous studies are still partial and have not discussed the important issue of the $d$ unsustainability of cassava partnership in Lampung Province. This study aims to: 1) analyze the income of cassava farmers in partnership (partner cassava farmers) compare to non-partner cassava farmers, 2) analyze the factors that cause farmers to make partnerships, and 3) analyze the factors that lead to unsustainability cassava partnership in Lampung Province, Indonesia. 


\section{Materials and Methods}

\section{Time and place of research}

This research was conducted in Lampung Province. Determination of the research site was determined deliberately (purposive) with the consideration that Lampung Province is the largest cassava producer province in Indonesia. The study was conducted from July to September 2018.

\section{Population and Sampling Techniques}

This study uses a survey method at the cassava production centers and tapioca agroindustry centers in Lampung Province. Determining the location of tapioca agroindustry with two types of clusters, namely factories with a high degree of competition (the number of factories relatively high in a cassava production center) and clusters with a low degree of competition (very few factories in cassava production center). One tapioca factory was taken from each cluster, each production center in each cluster was taken by the number of cassava farmers in a representative manner (sampling method), namely partner farmers or ever been in partnership and non-partner farmers. The first cluster area was Central Lampung Regency and the second cluster was East Lampung Regency with a total sample of 126 cassava farmers (63 farmers conducted partnerships and 63 farmers had not been in cassava partnerships).

\section{Types and Data Collection}

The research data consisted of primary and secondary data. Primary data includes data on cassava farming, partnership supporting factors, partnership models, and contributing factors lead to the unsustainability of cassava partnership. Secondary data was taken from the agencies and institutions related to the objectives of this study, such as from the Department of Agriculture of Food Crops and Horticulture of Lampung Province and relevant agencies at the provincial and district levels.

\section{Data Analysis Methods}

Data were analyzed by descriptive quantitative method. Analysis of cassava farming by calculating the income of cassava farmers in the first planting season was calculated by subtracting the value of commodity sales with the production costs incurred (explicit cost). Based on previous research and theories, there have been taken several factors that influence farmer income which are net income, variable input prices, variable input numbers, output prices, total production (output), and fixed costs. Mathematically the amount of income can be formulated (BPS Lampung, 2018)

Description :

$$
\pi=\mathbf{Y} . \mathbf{P y}-\sum \mathbf{X}_{\mathrm{i}} \mathbf{P} \mathbf{x}_{\mathbf{i}}-\mathbf{B T T}
$$

$$
\begin{array}{ll}
\Pi & =\text { Income }(\mathrm{Rp}) \\
\mathrm{Y} & =\text { Production Yield }(\mathrm{kg}) \\
\mathrm{Py} & =\text { Price of production }(\mathrm{IDR}) \\
\mathrm{X}_{\mathrm{i}} & =\text { Factor of production }(\mathrm{i}=1,2,3, \ldots \mathrm{n}) \\
\mathrm{P}_{\mathrm{xi}} & =\text { Production factor price no.i }(\mathrm{Rp}) \\
\mathrm{BTT} & =\text { Total fixed costs }(\mathrm{Rp})
\end{array}
$$

Logistic regression was used to analyze the factors that influence farmer decisions to do partnership. The logit model is a non-linear regression model where the dependent variable is 
categorical. The most basic categories of logit models produce binary values such as numbers 0 and 1, hence they are often called binary logit. However, if more than 2 categories are used then ordinal logit regression or multinomial logit are employed. The dependent variables chosen in this study are land area $(\mathrm{X} 1)$, selling price $\left(\mathrm{X}_{2}\right)$, age $\left(\mathrm{X}_{3}\right)$, education $\left(\mathrm{X}_{4}\right)$, farming experience $\left(\mathrm{X}_{5}\right)$, dependant family members $\left(\mathrm{X}_{6}\right)$, and farming income.

\section{Results and Discussion}

\section{Characteristics of Respondent}

The age of farmer is one of the important determinants in the success of a farming business that been running. It can be due to the success is related to the physical and mental condition of farmers. The age group of 40-58 had the largest percentage, which was equal to 68,25\% in partner farmer respondents and aged 21-39 years with a percentage of 53,97\% in non-partner farmer respondents. The highest level of education of partner farmers was Elementary School (SD) level of 30 people with a percentage of $47,62 \%$ and the lowest level of education of partner farmers was the level of Diploma or Bachelor with 2 persons with a percentage of $3,17 \%$.

Table 1: Distribution of partner and non-partner farmers based on education level

\begin{tabular}{lcccc}
\hline \multirow{2}{*}{\begin{tabular}{c} 
Education \\
\cline { 2 - 4 }
\end{tabular}} & \multicolumn{2}{c}{ Partner Farmer Respondents } & $\begin{array}{c}\text { Non Partner Farmer } \\
\text { Respondents }\end{array}$ \\
\cline { 2 - 5 } & Total (Person) & Percentage (\%) & Total & Percentage \\
\hline Haven't finished Elementary & 3 & 4,76 & 7 & 11,11 \\
Elementary School & 30 & 47,62 & 25 & 39,68 \\
Junior High School & 16 & 25,40 & 12 & 19,05 \\
High School & 12 & 19,05 & 17 & 26,98 \\
Diploma/ Bachelor & 2 & 3,17 & 1 & 1,59 \\
\hline \multicolumn{1}{c}{ Total } & 63 & 100 & 63 & 100 \\
\hline
\end{tabular}

The highest number of dependant family members of partner farmer ranged from 3 to 4 people with a percentage of $66,67 \%$ and the highest number of dependant family members of non-partner farmer ranged from 3 to 4 people with a percentage of $69,84 \%$. The partner farmer respondents who did not have family members as their responsibility then had no dependant family member (0).

Total of 28 partner farmers did not have side job with the percentage of 44,44\%. Off farm activities carried out by partner farmer respondents were livestock, agricultural transportation providers, tapioca factory employees, farm laborers and rubber tappers, while the non-farm activities carried out were self-employed/entrepreneur and construction workers. The majority of side job of non-partner farmer respondents was in non farm activities with 23 people with a percentage of $36,51 \%$.Non-farm activities of non-partner farmers included self-employed/entrepreneurs, construction workers, and drivers. Farmers who have farming experience of 17-31 years were 41 people with the highest percentage of $65,08 \%$, while the lowest percentage was $11,11 \%$ with experience of 7-16 years. 
Table 2: Farming experiences of partner and non-partner farmer respondents

\begin{tabular}{ccccc}
\hline \multirow{2}{*}{ Farming Experience } & \multicolumn{2}{c}{ Partner Farmer Respondents } & \multicolumn{2}{c}{ Non Partner Farmer Respondent } \\
\cline { 2 - 5 } & Total (Person) & Percentage $(\%)$ & Total (Person) & Percentage (\%) \\
\hline $2-16$ & 7 & 11,11 & 40 & 63,49 \\
$17-31$ & 41 & 65,08 & 21 & 33,33 \\
$32-45$ & 15 & 23,81 & 2 & 3,17 \\
\hline Total & 63 & 100 & 63 & 100 \\
\hline
\end{tabular}

The average land area used by partner farmer respondents was $0.5-1$ ha with a percentage of $52,38 \%$ and that the average land area used by respondents of non-partner farmers was $0.5-1$ ha with a percentage of $52,38 \%$.

Table 3. Distribution of land area of partner and non-partner farmer respondents in Lampung Province

\begin{tabular}{ccccc}
\hline \multirow{2}{*}{ Land Area } & \multicolumn{2}{c}{ Partner Farmer Respondents } & \multicolumn{2}{c}{ Non Partner Farmer Respondent } \\
\cline { 2 - 5 } & Total (Person) & Percentage $(\%)$ & Total (Person) & Percentage (\%) \\
\hline$<0,5$ ha & 9 & 14,29 & 7 & 11,11 \\
$0,5-1$ ha & 33 & 52,38 & 33 & 52,38 \\
$>1$ ha & 21 & 33,33 & 23 & 36,51 \\
\hline Total & 63 & 100 & 63 & 100 \\
\hline
\end{tabular}

The land ownership status of the partner farmer respondents had the highest percentage of $98,14 \%$. While, the lowest percentage was equal to $1,59 \%$ with 1 partner farmer and the ownership status of the land was self-owned. Ownership status of owned land had the highest percentage of $88,89 \%$ with 56 non-partner farmers. Followed by the ownership status of rental land of 4,76\% with the 3 nonpartner farmers and the ownership status of land ownership of $3,17 \%$ with 2 partner farmers. The ownership status of owned land and rental land was 3,17\% with 2 non-partner farmers.

\section{Partnership of Cassava Farmers}

According to Hafsah (2000), partnership is a business strategy carried out by two or more parties within a certain period of time to gain profits for those involved with the principle of mutual need and mutual rearing. The previous partnership process was either directly conducted with the factory or mediated by another party. The process of the partnership between cassava farmers and factories/companies is shown in Table 4.

Table 4: The process of partnership between cassava farmers and factories/companies

\begin{tabular}{lcc}
\hline \multicolumn{1}{c}{ The Process of Partnership } & Total (Person) & Percentage (\%) \\
\hline $\begin{array}{l}\text { Direct approached to the factories without mediation by the } \\
\text { government }\end{array}$ & 10 & 15,87 \\
Direct approached to the factories mediated by third party & 53 & 84,13 \\
\hline Total & 63 & 100 \\
\hline
\end{tabular}


Based on Table 4, it can be seen that most of the partnerships occur between cassava farmers and tapioca factories are mediated by third party with a percentage of $80,95 \%$. This third party becomes the coordinator or group leader in the partnership between cassava farmers and tapioca factories. Group leaders will submit themselves as parties who wish to do partnership with the factory. Requirements to submit as a partner are usually photocopies of KTP (Indonesian identity card) and KK (family registration) members who want to partner with the factory.

The form of cooperation between tapioca factories and cassava farmers, namely tapioca factories provide capital assistance in the form of seeds, fertilizers, and farmers are given training and guidance on good cultivation techniques to achieve maximum production. Most farmers are partnering with tapioca factories and their cropping patterns are not regulated. There was 61 respondents from partner farmers whose cropping patterns were not regulated with a percentage of $96,83 \%$, while the cropping pattern that was regulated had a percentage of $3,17 \%$ with the number of partner farmers as many as 2 farmers.

The price of cassava received by partner farmers is fixed according to the agreed contract or the price is set by the factory, and there are those who follow the market price. Whereas for non-partner farmers the price received follows the market. The price of cassava can be seen in Table 5.

Table 5:. Pricing of cassava

\begin{tabular}{ccc}
\hline Pricing & Total (Person) & Percentage (\%) \\
\hline Change according to market & 57 & 90,48 \\
Price Set by Factory & 6 & 9,52 \\
\hline Total & 63 & 100 \\
\hline
\end{tabular}

\section{Farming Income of Partner Cassava Farmers}

Total income of cassava farmers who have partnered and non-partner cassava farmers is different, this is due to differences in the amount of production produced by farmers. The average production of partner cassava farmers is different from the production of non-partner cassava farmers. The production of cassava farmers who had partnered and non-partners produced were $22.098,10 \mathrm{~kg} / \mathrm{ha}$ and $16.555,32 \mathrm{~kg} / \mathrm{ha}$. The amount of production produced by cassava farmers has not reached the maximum that can be obtained which is 16-20 tons/ha. This is due to the use of production facilities by farmers have not been as recommended. To achieve maximum production, the seeds need to be reduced, the provision of urea and NPK fertilizer needs to be increased based on the given recommendations.

Table 6: Results of different test analysis of income and cost of cassava farming between partner farmers and non-partners famers

\begin{tabular}{lrrrr}
\hline $\begin{array}{c}\text { Information } \\
\text { (Per ha) }\end{array}$ & Partner Farmer & Non Partner Farmer & t-calculated & Sig. \\
\hline Income & $29,545,786.49$ & $29,780,866.64$ & & \\
Cash Fee & $6,690,321.69$ & $6,961,822.44$ & & \\
Total Cost & $11,838,739.11$ & $10,417,168.46$ & & \\
Cash Income & $22,855,464.79$ & $13,819,044.20$ & 2,62 & 0,010 \\
Total Income & $17,707,047.38$ & $10,363,698.19$ & 2,43 & 0,017 \\
\hline
\end{tabular}


Cash income of partner cassava farmers was $\mathrm{Rp} 22,855,464.79$ per ha and cash income of nonpartner cassava farmers was Rp 13,819,044.20. Based on farming business, it can be seen that farmers who had partnered had higher income compared to those who had never been in partnership.

\section{Factors Affecting Farmers' Decisions to Conduct Partnerships}

To find out the factors that influence farmers' decisions to conduct partnerships, this study used binary logit analysis. Analysis of binary logit was used because the independent variable consists of two categories, namely partnerships and non-partnership. Non-independent variable (Y) is a farmer's decision where $1=$ farmers' decision to do partnership and $0=$ farmer's decision not to do partnership. The farmer's decision to conduct partnership is thought to be influenced by several factors, namely land area, selling price, age, education, farming experience, number of dependant family members, and farming income. The results of binary logit analysis can be seen in Table 7.

Table 7: Results of binary logit regression analysis of factors influencing the decision of cassava farmers in conducting partnerships in Lampung Province

\begin{tabular}{lrrrrc}
\hline \multicolumn{1}{c}{ Variable } & Coefficient & Std. Error & z-Statistic & Prob. & Odd rasio \\
\hline Constants & -0.506689 & 1.673748 & -0.30273 & 0.7621 & 0.6024 \\
X $_{1}$ (land area) & -1.068031 & 0.336044 & -3.17824 & 0.0015 & 0.3436 \\
X $_{2}$ (selling price) & -0.000535 & 0.000689 & -0.77649 & 0.4375 & 0.0999 \\
$\mathrm{X}_{3}$ (age) & -0.039239 & 0.024091 & -1.62882 & 0.1034 & 0.9615 \\
$\mathrm{X}_{4}$ (education) & 0.081038 & 0.070048 & 1.156888 & 0.2473 & 1.0844 \\
$\mathrm{X}_{5}$ farming experience & 0.09017 & 0.028755 & 3.135811 & 0.0017 & 1.0943 \\
$\mathrm{X}_{6}$ dependant family members & 0.090431 & 0.204596 & 0.441999 & 0.6585 & 1.0946 \\
$\mathrm{X}_{7}$ farm income & $5.90 \mathrm{E}-08$ & $1.83 \mathrm{E}-08$ & 3.2213 & 0.0013 & 1.0000 \\
\hline
\end{tabular}

Based on Table 7, it can be seen that there are 3 variables from 7 independent variables that have significant effect on farmers' decisions in partnering at significance alpha level of 10 percent which were land area, cassava farming experience, and farm income.

1. Cassava Land Area (X1) on Partnership Decision (Y)

The cassava land area variable has a $p$ value of 0.0015 which means that the land area of cassava has significant effect on the farmers' decision to do partnerships at significance level of 10 percent. Odd ratio value for the cassava land area variable is less than one which is equal to 0.3436 which means that the land area has a negative relationship with the farmers' decision to do partnership. This means that each farmer experiences an increase in land area of one unit, the larger land planted with rice will add to the costs that must be incurred by farmers but the greater the average production produced.

2. Cassava Farming Experience (X5) on Partnership Descision (Y)

The cassava farming experience significantly affected the decision to do partnership with significance level of 10 percent. The $p$ value is 0.0017 and the odd ratio value is more than one, it means that farming experience has a positive effect on the decision to do partnership. These results indicate if the farming experience increases by one unit, then the opportunity to partner will increase 1.0943 times than before, ceteris paribus. 
3. Farming Revenue Level (X7) on Partnership Decision (Y)

Cassava farming income has a significant effect on partnering decisions with significance level of 10 percent. The $\mathrm{p}$ value is 0.0013 and the odd ratio value is more than one, it means that farming experience has a positive effect on the decision to do partnership. The Odds value of 1.00 indicates that the tendency for farmers to partner will increase by 1,00 times, each farmer experiences one-unit increase in income.

\section{Factors Leading to Partnership Unsustainability}

The cassava agribusiness partnership has long begun since 1985, but until 2017 many have ended. The partnership that took place between the tapioca factory and cassava farmers did not last long, the longest lasting for 8 years. The age of cassava agribusiness partnerships among farmers who are members of the cassava farmer group and tapioca factories is not more than 10 years and some are even less than one year old.

The unsustainability of the cassava agribusiness partnership is shown to be a long time partnership between farmers and current factories that also shows the resilience of the partnership. Figure 23 shows that most farmers partnered with a tapioca factory for one year $(47,92 \%)$ then followed by a partnership for two years $(20,83 \%)$. The facts show that many factors cause the partnership to discontinue. This happens because throughout the partnership journey, the role of third parties diminishes and disappears, thus the communication between cassava farmers and manufacturers runs informally and increasingly leads to individual communication. This then adds to the factors leading to the cease of partnership.

Table 8. Reasons for Unrenewed (Discontinue) Partnership

\begin{tabular}{clrr}
\hline No. & The reason for unrenewed partnership & N & \multicolumn{2}{c}{ Percentage (\%) } \\
\hline 1 & Debt expenses & 2 & 3.17 \\
2 & The contract was terminated by the factory & 16 & 25.4 \\
3 & Expired contract with the factory & 5 & 12.7 \\
4 & Many collectors/stalls & 7 & 7.94 \\
5 & Have their own capital and want to be independent & 3 & 11.11 \\
6 & No clarification from the factory & 1 & 4.76 \\
7 & No coordination between factories and groups & 10 & 1.59 \\
8 & Different from the initial agreement & 11 & 15.87 \\
9 & Others & 63 & 17.46 \\
\hline & Total & & 100.00 \\
\hline
\end{tabular}

The unsustainability of the cassava partnership is caused by several factors such as farmers who do not want to be bound by cooperation with the factory. By not cooperating, farmers can freely decide the suitable price. In addition, the price of cassava and the discount is different from the initial agreement causes farmers do not want to cooperate with the factory. The facts show that at harvest

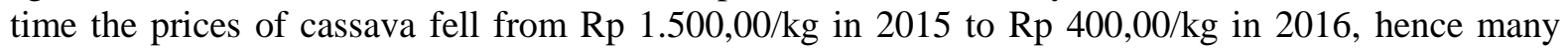
farmers suffered losses because the cost of producing and renting land was expensive and farmers did not harvest the production yield because harvesting cost and transportation cost were also high. As a result, the tapioca factory did not receive cassava raw material supplies in the coming season. The 
process of ending farmer-to-factory partnerships is carried out in several ways, some of which are due to the initiative of the farmers themselves, through coordination or the factories terminates the partnerships. The process of ending the partnership can be seen in Table 9 .

Table 9. The process of ending the cassava partnership

\begin{tabular}{|c|c|c|}
\hline $\begin{array}{c}\text { The Process of Partnership } \\
\text { Termination }\end{array}$ & Total (Person) & Percentage $(\%)$ \\
\hline Individual initiative & 41 & 65,08 \\
\hline Coordinated & 4 & 6,35 \\
\hline $\begin{array}{l}\text { Factories terminates the partnership } \\
\text { (unrenewed) }\end{array}$ & 18 & 28,57 \\
\hline Total & 63 & 100 \\
\hline
\end{tabular}

Most partnerships ended due to initiatives from partner farmers with a percentage of $65,08 \%$. Farmers do not want to be tied to tapioca factory or do not want to have debt are factors leading to the cease of the partnership. The incompatibility of the price and the discount on the initial agreement caused the farmer decides to discontinue the partnership with another tapioca factory. Some factors cause farmers to end partnership with tapioca factories:

1. Farmers as partner members who have been given capital assistance from partner factories violate the agreement by not selling their crops to the factory.

2. Prices determined by partners are cheaper compared to other factories that do not have partnerships with the farmers.

3. Partner factories buys the cassava with cheap price to farmers during holidays and new school year. This encourages farmers to sell their crops to other factories to meet the increasing needs at these times.

Many partnering farmers do not sell crops to partner factories. The absence of severe sanctions causes farmers to prefer to sell their crops to other factories at higher prices. The reason farmers sell cassava to other factories at higher prices is because at certain times such as holidays and new school year, partner factories actually reduce the price. Even though at that time the farmer needed a lot of money because of the increasing needs. Farmers inevitably sell their crops to other factories to meet their increasing needs. The lack of loyalty between the two parties led to the break off of partnership between tapioca factories and cassava farmers. These things above caused the unsustainability of the cassava partnership in Lampung Province

\section{Conclusion}

Cash income of partner cassava farmers was $\mathrm{Rp} 22,855,464.79$ per ha and cash income of nonpartner cassava farmers was Rp 13,819,044.20. Based on these data, it is obtained the fact that farmers who make partnerships (partner farmers) have higher income compared to non-partner farmers. The factors that influence the decision of cassava farmers in conducting partnerships were land area, cassava farming experience, and farming income. Although promising, many partnership 
patterns of agricultural products, particularly cassava in Lampung, have ceased (break off of partnerships). The break off of cassava partnership in Lampung Province was caused by the violations committed by farmers by selling their crops to other companies/factories and then the company/factory paid cheaper price compared to other companies/factories that did not conduct partnerships with farmers.

\section{References}

Abidin, A. Z., \& Devi, C. (2013). Development of Wet Noodles Based on Cassava Flour. J. Eng. Technol. Sci.,Vol.45, No. 1, 2013, 97-111, 45(1), 97-111. https://doi.org/10.5614/j.eng.technol.sci.2013.45.1.7

Anggraini, N., Hasyim, A. I., \& Situmorang, S. (2013). Analysis of Marketing Efficiency of Cassava in Lampung Province. Jurnal Ilmu-Ilmu Agribisnis, 1(1), 80-86. Retrieved from http://jurnal.fp.unila.ac.id/index.php/JIA/article/view/135/139

Asnawi, R. (2003). Analisis Fungsi Produksi Usahatani Ubikayu Dan Industri Tepung tapioka rakyat di Provinsi Lampung. Jurnal Pengkajian Dan Pengembangan Teknologi Pertanian, 6(2), 131140. Retrieved from http://ejurnal.litbang.pertanian.go.id/index.php/jpengkajian/article/view/1487/1266

BPS Lampung, B. L. (2018). Provinsi Lampung Dalam Angka 2018. (I. P. and D. S. Division, Ed.). Bandar Lampung: BPS Lampung.

Echebiri, R., \& Edaba, M. (2008). Production and Utilization of Cassava in Nigeria: Prospects for Food Security and Infant Nutrition. Production Agriculture and Technology, 4(1), 38-52. Retrieved from http://www.patnsukjournal.net/Vol4No1/p5.pdf

Fitriani, F., Unteawati, B., Mutaqin, Z., \& Sutarni, S. (2018). The Mapping of Agroindustry Based on Cassava. In IOP Conference Series: Earth and Environmental Science (p. 209 012019). https://doi.org/10.1088/1755-1315/209/1/012019

Hermiati, E., Mangunwidjaja, D., Sunarti, T. C., Suparno, O., \& Prasetya, B. (2012). Potential utilization of cassava pulp for ethanol production in Indonesia. Scientific Research and Essays, 7(2), 100-106. https://doi.org/10.5897/SREX11.022

Kamal, M., Hadi, M. S., \& Hariyanto, E. (2014). GRAIN YIELD AND , NUTRIENT AND STARCH CONTENT OF SORGHUM ( Sorghum bicolor ( L .) Moench ) GENOTYPES AS AFFECTED BY DATE OF INTERCROPPING WITH CASSAVA IN LAMPUNG , INDONESIA. J. ISSAAS, 20(1), 64-76.

MoA. (2016). Outlook: Komoditas Pertanian Sub Sektor Tanaman Pangan (Ubi Kayu). Jakarta: Ministry of Agriculture of Indonesia.

Montes, S. D. S., Rodrigues, L. M., Cardoso, R. de C. V., Camilloto, G. P., \& Cruz, R. S. (2015). Tapioca And Rice Flour Cookies: Technological, Nutritional And Sensory Properties. Ciênc. Agrotec., Lavras, 39(5), 514-522. https://doi.org/10.1590/S1413-70542015000500010 
Siburiaan, D. P., Sebayang, T., \& Sihombing, L. (2013). Analisis Usahatani Dan Pemasaran Ubi Kayu Dan Ubi Jalar Di Simalungun. Journal on Social Economic of Agriculture And Agribusiness, 2(4), 1-10.

Sugiharto, S., Yudiarti, T., Isroli, I., Widiastuti, E., \& Putra, F. D. (2017). Effects of feeding cassava pulp fermented with Acremonium charticola on growth performance , nutrient digestibility and meat quality of broiler chicks. South African Journal of Animal Science, 47(2), 130-138.

Sugino, T., \& Mayrowani, H. (2009). The determinants of cassava productivity and price under the farmers' collaboration with the emerging cassava processors : A case study in East Lampung, Indonesia. Journal of Development and Agricultural Economics, 1(5), 114-120. Retrieved from http://www.academicjournals.org/app/webroot/article/article1379604312_Sugino and Mayrowani.pdf.

Thamrin, M., Merdhiyah, A., \& Marpaung, S. E. (2013). Analisis Usahatani Ubi Kayu (Manihot utilissima). Agrium, 18(1), 57-64. Retrieved from

http://jurnal.umsu.ac.id/index.php/agrium/article/viewFile/343/310

\section{Copyrights}

Copyright for this article is retained by the author(s), with first publication rights granted to the journal. This is an open-access article distributed under the terms and conditions of the Creative Commons Attribution license (http://creativecommons.org/licenses/by/4.0/). 